\title{
Pääkirjoitus
}

\section{SIGNUMIN PAIKKA JA MERKITYS}

Signumin tulevaisuus puhututtaa jälleen. Edellisessä numerossa avattiin hieman Suomen tieteellisen kirjastoseuran (sTKs) hankalaa taloustilannetta, joka heijastuu myös painetun lehden tulevaisuuteen. Kysymys on siis lähinnä siitä, missä muodossa Signum jatkossa ilmestyy.

Jotta lehteä koskevassa päätöksenteossa olisi talouslukujen lisäksi kaikki olennainen informaatio käytössä, seura järjestää jäsenille Signumia koskevan kyselyn touko-kesäkuussa. Kyselyyn voi vastata kesäkuun loppuun mennessä.

Signum ei ole ensi kertaa tienhaarassa. Tuula Ruhasen ja Marja Sarvilinnan toimittamasta sTKs-historiikista, $\mathrm{Muu-}$ toksen tekijät hyvässä seurassa (20 I 8), löytyy aikalaistekijöiden kuvaus Signumin vaiheista aina perustamisvuodesta 1968 pitkälle 20 Io-luvulle asti.

Martti Blåfieldin, Tuula Ruhasen ja Päivikki Karhulan kirjaan kirjoittamasta artikkelista, Signum-lehti-tieteellisten kirjastojen yhteinen ääni, erottuu ainakin kaksi punaista lankaa. Yhtäältä Signumin kohdalla on keskusteltu taloudesta, toisaalta siitä, mitä varten lehti on olemassa.

Talous mainitaan tekstissä isoimpana ongelmana, kahleena ja murheenkryyninä. Vuotuinen ilmestymistahti on pudonnut vuosikymmenten aikana kymmenestä neljään, ja I 990-luvun lamavuosina keskusteltiin jopa lehden lopettamisesta.

Pysäyttävimmän todistajanlausunnon antaa lehden ensimmäinen päätoimittaja Martti Blåfield: "Eräänä vuonna maksoin perheeni asuntolainalla Signumin kirjapainolaskunkin, koska tuntui siltä, ettei taas voi pyytää seuroilta lisää.” Tähän verrattuna nykyinen taloustilanne on sentään valoisampi, ja seuran toimi- henkilöt ovat saaneet keskittyä ydintehtäviinsä tukitoimien sijasta.

Lehdentekijän ja lukijan näkökulmasta kiinnostavin kysymys koskee Signumin sisältöjä ja julkaisun olemassaolon tarkoitusta. Historian tarkastelu antaa tähänkin perspektiiviä.

2000-luvun digitaaliseen murrokseen asti painettu lehti toimi tieteellisten kirjastojen keskeisenä tiedotuskanavana. Tiedotettavaa riitti virallisista ilmoituksista, tapahtumista ja seurojen uutisista laajempiin kirjastoalan kehityslinjoihin, uusiin teknologioihin ja lisääntyviin yhteistyömuotoihin.

I990-luvulta lähtien varsinaiseen tiedotukseen on tullut luontevampia kanavia, kuten sähköposti, verkkosivut ja sosiaalinen media. Signum on jatkanut kuitenkin ilmestymistään, ja alan monisäikeisen kehityksen seurantaan, analysointiin ja laajempaan keskusteluun lehti onkin tarjonnut hyvän foorumin. Ja tarjoaa yhä: tieteellisiä kirjastoja koskevan informaation paljous ja muutosten nopeus luo kasvavan tarpeen tiedon jäsentämiselle ja lukijaystävälliselle välittämiselle myös ammattilehden kautta.

Tämän pääkirjoituksen pääviesti on tämä: vastatkaa Signumia koskevaan jäsenkyselyyn. Vain riittävän edustava vastaajajoukko antaa hallitukselle tukevan selkänojan päätöksentekoon.

Jäsenkyselyn lopussa on kenttä vapaaseen kommentointiin. Täyttäkää sekin. Ajatuksillanne lehden suhteen on merkitystä. Mikä on Signumin paikka ja miten se voisi pysyä merkityksellisenä myös tulevaisuudessa?

Juuso Ala-Kyyny 